\title{
KEMITRAAN PENDIDIKAN ANAK USIA DINI (SINERGI TIGA PILAR PENDIDIKAN: KELUARGA, SEKOLAH DAN MASYARAKAT)
}

\author{
Jamilah \\ Program Studi Pendidikan Guru Sekolah Dasar \\ STKIP PGRI Sumenep \\ jamilah@stkippgrisumenep.ac.id
}

\begin{abstract}
The purpose of this study is to describe the partnership of early childhood education between school families and the community. This type of research was a qualitative deskriptif approach. The research subjects were parents, educators and managers. Data were collected through interviews, observation, and document study. The data were analyzed using the qualitative analysis techniques data collecting, data display and conclusion drawing. The results showed that the relationship of partnerships and cooperation between PAUD institutions and parents and the community of students can be achieved to the maximum and increase the role of parents of early childhood and the community in the implementation of early childhood education institution programs.
\end{abstract}

Keywords: partnership, parents, school, society

\begin{abstract}
Abstrak
Tujuan dari penelitian ini adalah mendeskripsikan kemitraan pendidikan anak usia dini antara keluarga sekolah dan masyarakat. Jenis penelitian ini adalah kualitatifdengan pendekatan deskriptif. Subjek penelitian ini adalah para orang tua pendidik dan pengelola Pengambilan data dilakukan melalui wawancara, observasi, dan studi dokumen. Data penelitian ini dianalisis menggunakan teknik kualitatif diantara pengumpulan data, penyajian data dan penarikan kesimpulan. Hasil penelitian menunjukkan bahwa hubungan kemitraan dan kerjasama antara lembaga PAUD dengan orang tua dan masyarakat peserta didik bisa dicapai secara maksimal dan meningkatkan peranan orang tua anak usia dini dan masyarakat dalam pelaksanaan program-program lembaga PAUD.
\end{abstract}

Kata Kunci: kemitraan, orang tua, sekolah, masyarakat 


\section{PENDAHULUAN}

Mutu pendidikan saat ini merupakan salah satu persoalanyang ada dalam dunia pendidikan, khususnya dalam program pendidiakan anak usia dini. Menurut Depdiknas (2002: 1) ada tiga faktor yang menyebabkan mutu pendidikan di Indonesia tidak merata: 1) kebijakan pendidikan dengan menggunakan pendekatan production function atau inputoutput analysis. Menurut pendekatan ini sekolah merupakan pusat produksi yang melahirkan input dan menghasilkan output; 2) pendidikan yang dilaksanakan secara birokratik analitik sehingga sekolah tidak bisa mandiri dalam proses penyelenggaraannya; 3) keterlibatan stakeholders masih minim. Misalnya keputusan sekolah sering diabaikan terutama guru. Padahal guru merupakan ujung tombak dari perubahan sekolah. Orang tua dan masyarakat juga merupakan stakeholders yang selama ini diabaikan dalam pengelolaan pendidikan. Mereka memiliki kepentingan terhadap penyelenggaraan pendidikan yang baik di masyarakatnya.

Keluarga sebagai lembaga pendidikan yang pertama dan utama bagi seorang anak mempunyai andil yang sangat besar bagi perkembangan anak untuk menuju kehidupannya yang lebih komplek. Sementara itu, partisipasi orang tua dan masyarakat selama ini pada umumnya baru sebatas dukungan dana, sedangkan dukungan lain seperti pemikiran moral, pengelolaan, jasa kurang mendapat perhatian.

Ada beberapa alasan mengapa orang tua harus terlibat dalam program diantaranya: 1) Keinginan orang tua untuk terlibat, keinginan orang tua yang ingin terlibat secara penuh telah meningkat dari tahun ke tahun; 2) Peningkatan prestasi dan keterampilan sosial, ketika orang tua terlibat citra diri dan prestasi anak-anak akan terus meningkat, 3) Dukungan orang tua, orang tua lebih mendukung program di mana mereka memiliki kontak langsung dan memiliki keterlibatan bermakna; 4) Hak orang tua, pendidik anak usia dini mengakui bahwa orang tua memiliki hak untuk terlibat dalam program-program yang mempengaruhi mereka; 5) Tugas orang tua, setiap orang tua harus terlibat dalam beberapa cara untuk setidaknya ketika anak-anak mereka dalam program. Salah satu upaya yang dapat dilakukan untuk meningkatkan mutu pendidikan dan performa peserta didik adalah melalui penguatan kemitraan antara sekolah, orang tua, dan institusi-institusi kemasyarakatan yang terkait.

Salah satu kriteria PAUD yang berkualitas adalah memberikan pelayanan berdasarkan program yang berkualitas pula, sebagaimana yang diungkapkan oleh Wortham (2013: 47) bahwa PAUD yang berkualitas memiliki ciri-ciri sebagai berikut: 1) Berprinsip pada perkembangan anak. 2) Memiliki kurikulum yang seimbang. 3) Memperhatikan hubungan orang tua, guru dan anak. 4) Memberikan penilaian dan pertanggungjawaban. 5) Menghargai perbedaan anak dan keluarga. 6) Memperhatikan etika dan hubungan antar guru.

Pendapat di atas mengungkapkan bahwa PAUD yang berkualitas memiliki hubungan baik antara orang tua, anak dan guru atau dengan kata lain memasukkan partisipasi orang tua ke dalam program sekolah. Hal tersebut dilakukan karena mengingat bahwa anak usia dini pada 
dasarnya tidak dapat terlepas dari pengasuhan dan pengawasan orang tua, baik dalam lingkungan rumah maupun dalam lembaga pendidikan atau sekolah, di mana Mansur (2009: 339) menyatakan bahwa "orang tua memiliki tanggung jawab sejak akal pikiran anak belum sempurna sampai anak mampu menemukan dirinya atas tindakannya sendiri". Berdasarkan uraian di atas, akan dikembangkan model kemitaraan orang tua sekolah yang tepat dengan karakteristik masyarakat setempat. Sehingga proses penyelenggaraan pendidikan di sekolah dapat berlangsung secara optimal.

Sekolah sebagai salah satu lembaga formal yang memang dengan sengaja dirancang sebagai tempat belajar, tempat untuk berkomunikasi antara guru dan murid, yang difasilitasi dengan peralatan belajar (laboratorium, perpustakaan, olah raga, music, teknologi informasi) maka di sekolah seolah-olah sebagai tempat yang khusus untuk melaksanakan kegiatan pendidikan atau belajar. Namun demikian sekolah bukan identik dengan pendidikan, karena aktivitas pendidikan terjadi secara luas baik dalam keluarga, masyarakat, maupun tempat kerja.

Kemitraan orang tua dalam sekolah memberikan manfaat penting bagi prestasi peserta didik adalah memberikan sumber daya untuk menambah serrta melengkapi keberadaan peluang program untuk pembaharuan staf dan inovasi program sekolahi, serta dukungan orang tua dalam hal politik (Keith dan Girling, 1991). Beberapa alasan utama yang mendasari pentingnya melibatkan orang tua dalam pendidikan di lembaga pendidikan menurut Epstein (1991) dalam Brewer (2007: 238) adalah: 1) orang tua dan guru lebih banyak memiliki kesamaan dibandingkan perbedaan dalam mendidik anak. Mereka banyak memiliki tujuan dan kebutuhan yang perlu dibagi satu dengan lainnya, 2) keterlibatan orang tua dalam program tidak hanya berhenti pada pendidikan anak, tetapi sebaiknya berlanjut sampai pada jenjang berikutnya, 3) program yang disusun lembaga pendidikan melibatkan semua anggota keluarga, 4) program yang disusun lembaga pendidikan menjadikan tugas guru menjadi lebih mudah, dan 5) program berkembang seiring dengan waktu.

Manfaat kemitraan orang tua dalam pendidikan bagi orang tua meliputi: (1) orang tua berusaha meningkatkan interaksi dan diskusi dengan anak-anak mereka, dan menjadi lebih tanggap serta peka terhadap kebutuhan sosial, emosional, dan perkembangan intelektual anak, (2) orang tua akan semakin percaya diri dalam mengasuh anak-anak mereka, (3) orang tua mendapat pengetahuan dan pemahaman tentang perkembangan anak-anak mereka, sehingga mereka akan menjadi lebih mampu memberikan cinta kasih dan penguatan serta mengurangi hukuman bagi anak-anak mereka, (4) orang tua memiliki pemahaman yang lebih baik tentang peranan guru dan kurikulum sekolah, (5) ketika orang tua mengerti apa yang sedang dipelajari oleh anak-anak mereka, mereka menjadi lebih semangat untuk membantu anakanaknya belajar di rumah, (6) kepedulian orang tua terhadap sekolah meningkat dan kebulatan tekad serta komitmen mereka terhadap sekolahpun semakin kuat, dan (7) orang tua menjadi lebih sadar dan menjadi lebih aktif dalam memberikan perhatian serta bantuan 
terhadap pendidikan anak mereka ketika diminta oleh sekolah untuk ambil bagian dalam tim pengambil keputusan.

Manfaat kemitraan masyarakat dalam pendidikan bagi guru meliputi: (1) para guru dan kepala sekolah akan mendapatkan nilai moral yang lebih tinggi dalam pandangan orangtua, (2) para guru dan kepala sekolah akan mendapat penghargaan yang lebih tinggi atas profesi mereka dari pihak orangtua, (3) pelibatan orang tua secara konsisten yang akan meningkatkan komunikasi dan hubungan yang baik antara pihak orangtua, guru, dan para pegawai, (4) para guru dan kepala sekolah merasakan adanya peningkatan kepuasan kerja di dalam diri mereka. Bagi sekolah, manfaat yang dapat diambil dari keterlibatan orang tua dalam pendidikan meliputi: (1) sekolah-sekolah yang aktif melibatkan orang tua dan masyarakat cenderung memiliki reputasi yang lebih baik di masyarakat, (2) sekolah.

Keberhasilan hubungan sekolah dan orang tua dilandasi oleh adanya kepercayaan dan saling pengertian. Sekolah perlu menunjukkan ketulusan kepada orang tua bahwa mereka benar-benar peduli dengan kemajuan anak. Di masa awal sekolah upaya membangun hubungan dengan orangtua tentunya sangat menantang dan tingkat keikutsertaan rendah. Tapi setelah tercapai kepercayaan itu, orangtua kemudian mau terlibat dan semua tertuju pada satu arah yaitu kemajuan anak.

Bahkan di tempat rekreasi untuk mengisi waktu luangpun terjadi aktivitas pendidikan atau belajar. Sekolah tidak berada pada ruang hampa yang steril dari pengaruh kekuatan-kekuatan sosial yang lain. Kekuatan masing- masing elemen tersebut akan berarti manakala digerakkan secara sinergis untuk mendukung aktivitas pendidikan. Elemen-elemen kekuatan sosial tersebut, dalam bahasa para sosiolog sering dikenal dengan istilah social capital atau modal sosial.

Oleh karenanya teori pertama yang menjadi basis kajian kemitraan dalam pendidikan adalah teori modal sosial (social capital theory). Selain mengkoordinir kekuatan relasi sosial, dalam prakteknya kemitraan antara sekolah, keluarga, dan masyarakat terjadi pendistribusian kerja dan kewenangan. Sekolah, keluarga, dan masyarakat dapat saling mempertukarkan job sesuai dengan kemampuan masing-masing untuk mensupport pendidikan anak di sekolah. Pertukaran job dan kewenangan antar elemen ini dipandang mampu menyelesaikan "pekerjaan" dan masingmasing elemen saling diuntungkan. Model pertukaran pekerjaan dan kewenangan ini dalam bahasa para sosiolog dikenal dengan exchange theory atau teori pertukaran.

\section{METODE}

Penelitian ini menggunakan pendekatan kualitatif yang bertujuan untuk mengkaji permasalahan dan memperoleh makna yang lebih mendalam. Penelitian ini bersifat deskriptif artinya data yang dikumpulkan akan disajikan dalam bentuk kalimat (Sugiyono, 2011: 46) karakteristik penelitian kualitatif bersifat induktif, pengembangan konsep didasarkan atas data yang ada. Sumber data dari informan, dokumen dan penelitian di lapangan. Teknik pengumpulan data dengan wawancara, obeservasi, studi dokumen. 
Teknik pengumpulan data dengan menggunakan analisis interaktif (Milles and Huberman). Data penelitian ini dianalisis menggunakan teknik kualitatif diantara pengumpulan data, penyajian data dan penarikan kesimpulan.

\section{III.HASIL DAN PEMBAHASAN}

\subsection{Kemitraan Pendidikan dalam Keluarga}

Dalam konteks kemitraan antara sekolah, keluarga dan masyarakat, sekolah berperan sebagai mesin yang menyediakan jasa yang mempersatukan ketiga elemen tesebut. Kalau diperhitungkan secara seksama, mereka memiliki kepentingan yang saling melengkapi, dan oleh karenanya menghasilkan sejumlah transaksi. Relasi transaksi pendidikan antara sekolah, orang tua dan masyarakat. Dalam pola tersebut, sekolah menjadi mesin sentral yang menjadi perantara untuk mempersiapkan peran-peran sosial dalam keluarga dan masyarakat.

Namun, peran sentral sekolah sebagai mesin tidak akan dapat berfungsi secara maksimal tanpa transaksi-transaksi dengan orang tua dan masyarakat. Orang tua mempertukarkan uang atau barang dengan jasa yang disediakan di sekolah, yang berupa pendidikan untuk menjadikan anakanaknya baik, cerdas, dan terampil. Orang tua menginginkan anaknya menjadi individu yang baik, cerdas, dan terampil agar siap memainkan peran di masyarakat. Masyarakat berkepentingan dengan individu yang baik, cerdas, dan terampil dalam rangka untuk menjamin eksistensi dan stabilitas sosial. Guna mencapai keinginan tersebut, masyarakat menyediakan resources dan atau volunteer yang dapat dimanfaatkan sekolah untuk mengoptimalkan proses pendidikan.

Pemahaman orang tua terhadap kewajiban dan tanggung jawabnya dalam PAUD menjadi hal yang mendasar bagi kelancaran program PAUD itu sendiri. Peran aktif orang tua sangat diperlukan dalam mengarahkan anak dalam proses belajar mengajar maupun sebelum dan sesudah kegiatan pembelajaran itu berlangsung.

Hal ini sesuai dengan pendapat (Hornby, 2011: 32) yang menyatakan bahwa partisipasi orang tua pada umumnya berwujud dukungan orang tua dalam bentuk pendanaan dan terhadap hal-hal tertentu dalam pendidikan anak mereka seperti menghadiri kegiatan anak, mengantar dan menjemput anak, membayar uang sekolah. Pada tahap ini yang dinilai adalah kehadiran dan partisipasi orang tua dalam membantu PAUD untuk menyusun suatu program atau memberikan buah fikiran pada awal pelaksanaan kegiatan lembaga PAUD. Hal ini selaras dengan teori Beaty (1984: 206) yang mengatakan bahwa pada pertemuan awal dengan orang tua, pendekatan paling efektif adalah fokus pada anak, bukan pada program yang diselenggarakan di sekolah. Hal tersebut sesuai dengan pernyataan Morrison (2012: 372) bahwa partisipasi orang tua, apapun latar belakangnya, cenderung dapat meningkatkan pencapaian siswa dan mendorong hasil pendidikan yang positif. Hubungan tersebut berlaku bagi seluruh keluarga dari semua latar belakang ekonomi, ras/etnis, dan pendidikan. 
Dalam proses yang melibatkan orang tua dalam pembelajaran anak usia dini ketika mengacu pada pendapat Morrison (1988: 323) tentang kesiapan pendidik dalam merancang kegiatan pembelajaran yang melibatkan orang tua. Ada tiga tingkat kesiapan pendidik untuk melibatkan orang, maka dalam penelitian inimenunjukkan tingkat kesiapan guru dalam tingkat kedua yaitu kesiapan pasif.

Pentingnya partisipasi orang tua terhadap pelaksanaan program di PAUD yaitu untuk keberhasilan dan kemajuan program PAUD. Orang tua merupakan faktor pendorong utama dalam keberhasilan program PAUD. Pengetahuan orang tua mengenai informasi bahwa pentingnya pendidikan di masa golden age merupakan salah satu bentuk partisipasi orang tua. Tingkat kepercayaan para orang tua terhadap lembaga PAUD menjadi pintu utama bagi lembaga menuju keberhasilan program. Partisipasi orang tua anak usia dini adalah bentuk partisipasi orang tua dalam program pendidikan anak usia dini.

Peran serta dan partisipasi mereka yang ditunjukan dalam rapat, keikutsertaannya dalam mengemukakan pendapat, dan partisipasinya dalam monitoring dan evaluasi kegiatan. Partisipasi merupakan tingkat kerjasama yang minimum, misalnya orang tua datang dan membantu sekolah jika diundang dalam bentuk rapat wali murid. Partisipasi merupakan tingkat kerjasama yang lebih luas dan tinggi tingkatannya. Orang tua dan sekolah duduk bersama membicarakan berbagai berbagai program dan kegiatan anak.

\subsection{Kemitraan Pendidikan dengan Sekolah}

Partisipasi merupakan tingkat kerjasama yang minimum, misalnya orang tua datang dan membantu sekolah jika diundang dalam bentuk rapat wali murid. Partisipasi merupakan tingkat kerjasama yang lebih luas dan tinggi tingkatannya. Orang tua dan sekolah duduk bersama membicarakan berbagai berbagai program dan kegiatan anak.

Menurut Mulyasa (2007: 168-169), beberapa hal yang dapat dilakukan sekolah dalam rangka mengembangkan kemitraan dengan orang tua antara lain:

1. Melibatkan orang tua secara profesional dalam mengembangkan perencanaan, pelaksanaan, dan evaluasi program sekolah.

2. Menjalin komuikasi secara intensif dan proaktif. Untuk maksud tersebut, sekolah dapat melakukan hal-hal berikut. a. Mengucapkan selamat datang dan bergabung dengan sekolah, dewan pendidikan, dan komite sekolah bagi orang tua peserta didik baru. Lakukan perkenalan dan orientasi singkat tentang sekolah dan berbagai kegiatannya b. Mengadakan rapat secara rutin dengan orang tua, sehingga rapat dapat efektif dan mereka saling mengenal. c. Mengirimkan berita tentang sekolah secara periodik, sehingga orang tua mengetahui sekolah, program dan perkembangannya. d. Membagikan daftar tenaga kependidikan secara lengkap termasuk alamat dan nomor telepon dan tugas pokok, sehingga orang tua dapat berhubungan langsung dengan mereka jika 
diperlukan. e. Mengundang orang tua dalam rangka mengembangkan kreativitas dan prestasi peserta didik. f. Mengadakan kunjungan ke rumah untuk memecahkan masalah dan mengembangkan pribadi peserta didik g. Mengadakan pembagian tugas dan tanggung jawab antara sekolah dengan orang tua dalam pembinaan peserta didik. h. Melibatkan orang tua dalam berbagai program dan kegiatan di sekolah yang bersifat sosial kemasyarakatan, seperti bakti sosial, perpisahan, peringatan hari-hari besar, pentas seni. Pelibatan orang tua ini disesuaikan dengan hobi, kemampuan, dan pekerjaan mereka dengan program kegiatan yang akan dilakukan di sekolah. i. Melibatkan orang tua dalam mengambil berbagai keputusan, agar mereka ikut merasa bertanggung jawab untuk melaksanakannya. j. Mendorong guru untuk memberdayakan orang tua sebagai sumber belajar dan menunjang keberhasilan belajar peserta didik.

Disamping upaya-upaya tersebut, hal terpenting yang harus dilakukan pihak sekolah untuk meningkatkan partisipasi orang tua di sekolah adalah dengan merencanakan atau membuat program pelibatan orang tua di sekolah. Program pelibatan orang tua di sekolah dapat dirancang dalam berbagai bentuk yang tentunya harus disesuaikan dengan situasi, kondisi dan budaya orang tua dan guru yang ada di sekolah tersebut.

Jawaban atas masalah itu dapat menjadi pijakan dalam merumuskan program yang berbasis pada aspirasi dan kebutuhan orang tua, yang pada akhirnya mereka mendukung setiap program yang akan diimplementasikan di kelompok bermain. Adanya kesejajaran temuan yang dihasilkan dari penelitian ini dan beberapa penelitian yang sejenis mengindikasikan bahwa partisipasi orang tua dalam pengelolaan program pendidikan di kelompok bermain menjadi prasyarat bagi pengelolaan program pendidikan anak usia dini yang adaptif dengan lingkungan masyarakat setempat.

\subsection{Kemitraan Pendidikan dengan Masyarakat}

Masyarakat menyediakan sumbersumber daya (resources) yang diperlukan untuk kegiatan pendidikan di sekolah. Sumber-sumber tersebut mungkin ada yang memerlukan dan tidak memerlukan biaya untuk pemanfaatannya bagi sekolah. Sekolah sebagai pihak pelaksana praktis pendidikan harus mampu mengidentifikasi dan memanfaatkan secara optimal resources yang ada di masyarakat untuk kepentingan pendidikan di sekolah.

Beberapa hal yang harus diperhatikan dalam mengembangkan kemitraan sekolah dengan masyarakat adalah:

1. Pemimpin sekolah dan para pengambil kebijakan harus mendorong rekonseptualisasi sekolah negeri untuk memupuk pentingnya sumber sumber ekonomi.

2. Pihak sekolah dan organisasi sosial lainnya diharapkan menyediakan link layanan secara hati-hati dengan mempertimbangkan cakupan, 
kebutuhan dana, kompleksitas organisasi dan profesi, dan jenis layanan yang akan diberikan.

3. Mencari alternatif sumber pendanaan bagi proyek kegiatan bersama masyarakat dengan selalu menjaga konsistensi dan stabilitas. Semakin besar dan kompleks kegiatan, semakin besar pula membutuhkan pendanaan.

Beragam stakeholders di sekolah harus dijadikan mitra kerja, tidak hanya sebagai pendengar, namun juga dalam diskusi dan kegiatan-kegiatan untuk kepentingan perbaikan sekolah, meningkatkan performa siswa dan memperkuat peran keluarga. (Decker and Decker, 2003: 105).

Kemitraan antara sekolah, keluarga, dan masyarakat didesain untuk memfasilitasi jejaring agar dapat menarik berbagai ide dan sumber daya, berbagi pengalaman yang terbaik, dan mengenalkan kepada masyarakat luas akan pentingnya kemitraan. Hal demikian dapat menjaga agar tidak ketinggalan informasi dan trend pendidikan yang terbaru, penyediaan sumber-sumber daya, dan publikasi agar program yang lebih efektif dan kontekstual (Decker and Decker, 2003: 106).

Dalam bentuk praktis kemitraan antara sekolah dengan masyarakat dapat diwujudkan dalam beragam bentuk dan peran sesuai dengan kapasitas masing-masing. Misalnya perusahaan lokal dapat mensupport sekolah dengan menyumbangkan sumber daya yang dimilikinya dan waktu. Para pengusaha dapat menyumbangkankan peralatan, menyediakan tamu ahli, sebagai tuan rumah studi lapangan, atau menawarkan training magang bagi para siswa, sehingga para siswa memahami hubungan antara dunia sekolah dengan dunia kerja, dan mengetahui model peran baru untuk ditiru. Masyarakat mungkin juga memiliki budaya tertentu yang dapat direfleksikan di sekolah seperti budaya daerah, dimana sekolah dapat menyelenggarakan apresiasi budaya dan para siswa dapat berpartisipasi dengan bermain peran dengan menggunakan pakaian adat dalam budaya masyarakat tersebut.

\subsection{Faktor-Faktor yang Mempengaruhi Kemitraan}

Hasil temuan penelitian tentang faktor-faktor yang mempengaruhi kemitraan dalam penyelenggaraan PAUD menunjukkan tingkat:

a) Pendidikan masyarakat (orang tua) berpendidikan TK, SD, SMP, SMA, SI selalu memberi motivasi terhadap belajar anak dan mendukung belajar anak dengan semua fasilitas yang dibutuhkan untuk belajar, Orang tua yang berpartisipasi dalam lembaga PAUD rata-rata memiliki pendidikan yang lebih tinggi dibandingkan dengan orang tua yang tidak berpartisipasi. Orang tua yang berpartisipasi di lembaga PAUD paling rendah berpendidikan SD dan paling tinggi adalah S1, namun rata-rata berpendidikan SMA. Sedangkan orang tua yang tidak berpartisipasi di lembaga PAUD paling tinggi berpendidikan SMA dan sebagian besar berpendidikan SMP dan SD. Dari tingkat pendidikan orang tua menunjukkan bahwa orang tua 
yang berpendidikan lebih tinggi memiliki persepsi yang lebih baik tentang pendidikan anak usia dini dan lembaga PAUD dibandingkan dengan yang berpendidikan lebih rendah. PAUD paling tinggi berpendidikan SMA dan sebagian besar berpendidikan SMP dan SD.

b) Jenis pekerjaaan, orang tua yang memiliki pekerjaan tentunya mampu mendukung, menyetujui dan mendanai semua program yang diputuskan oleh sekolah, sesuai dengan sarat program tersebut sesuai dengan kebutuhan siswa dan peningkatan pestasi belajar anak yang akhirnya mampu meningkatkan kualitas pendidikan. Keadaan ekonomi keluarga juga mempengaruhi meskipun secara tidak langsung. Orang tua yang berpartisipasi di lembaga PAUD sebagian besar berpendapatan lebih tinggi daripada orang tua yang tidak berpartisipasi. Orang tua yang berpartisipasi di lembaga PAUD rata-rata berpenghasilan Rp 1.200.000 hingga Rp 2.500.000 perbulan, sedangkan orang tua yang tidak berpartisipasi di lembaga PAUD memiliki penghasilan ratarata kurang dari $\operatorname{Rp} 1.000 .000$ perbulan.

Berdasarkan perspektif Epstein (2002: 87) terdapat beberapa aspek yang mempengaruhi faktor relasi antar orang tua, lembaga dan msyarakat. Di bawah ini merupakan hasil temuan di lapangan gambaran relasi tersebut: 1) Pemberian informasi tentang
pengetahuan dan ketrampilan pengsuhan. Pemberian informasi ini dilakukan pada saat pertemuan orangtua dan guru. Hanya saja frekuensinya 1 kali dalam 1 semester, yaitu pada saat pembagian hasil belajar.

2) Pemberian tugas kepada anak didik yang harus dikerjakan bersama orangtua di rumah. Guru terkadang memberikan PR namun belum terlihat upaya berorientasi untuk melibatkan orangtua bersama anak dalam prosesnya. Selain itu guru enggan memberikan PR karena dianggapnya akan membebani anak didik.

3) Para guru belum memiliki wawasan dan pengetahuan untuk mendesain tugas yang menarik dan melibatkan orang tua dalam proses pengerjaannya.

4) Mengajak orang tua untuk menjadi relawan atau tenaga sukarela dalam kegiatan pembelajaran. Pihak lembaga pendidikan merasa tidak perlu melibatkan orang tua karena urusan pendidikan sepenuhnya tanggungjawab guru. Selama ini tidak ada program orangtua menjadi volunteer.

5) Melibatkan orang tua dalam pembuatan keputusan atau perencanaan kegiatan di lembaga. Pengelola lembaga tidak setuju bila orangtua terlibat dalam pengambilan keputusan atau perencanaan kegiatan di lembaga. karean mereka menganggap buka wewenang orang tua.

6) Komunikasi orang tua-guru. Komunikasi orang tua dan guru jarang dilakukan. Agaknya orang tua juga segan untuk bertanya banyak 
hal tentang anak mereka kepada guru. kurang ada inisiatif dari kedua belah pihak untuk melakukan komunikasi secara intensif untuk membicarakan perkembangan anak.

7) Kerjasama dengan orang tua. Belum dikembangkan program kolaborasi dengan orang tua.

Hal tersebut senada dengan pendapat Slamet Suyanto (2005: 226) yang menyatakan bahwa orang tua mengganggap mereka tidak bisa berbuat banyak dan guru jauh lebih kompeten di bidangnya. Berdasarkan hasil FGD antara pengelola PAUD Tarbiyatus Shibyan dan PAUD Mutiara Hati dan para stakeholders PAUD bahwa faktor yang menjadi kendala dalam partisipasi orang tua pada program PAUD yang paling tinggi adalah faktor waktu, dimana faktor ini menjadi penentu bisa atau tidaknya orang tua terlibat dalam kegiatan yang memberikan kesempatan untuk berpartisipasi.

\subsection{Model Kemitraan}

Model kemitraan sangat tergantung pada visi dan misi sekolah. Untuk mewujudkan hal tersebut perlu adanya kemitraan antara sekolah keluarga dan masyarakat, karena: 1) Keluarga adalah pendidik yang pertama dan utama, tetapi dalam praktiknya masih banyak keluarga yang menyerahkan sepenuhnya tanggung jawab pendidikan anak pada sekolah, 2) Peran sekolah adalah membantu keluarga agar pelaksanaan pendidikan lebih sistimatis, efektif, dan hasilnya tersertifikasi, 3) Tidak semua kebutuhan pendidikan anak dapat dipenuhi oleh satuan pendidikan maupun keluarga, 4) Kerjasama keluarga dengan satuan pendidikan dan masyarakat mutlak diperlukan, 5) Satuan pendidikan wajib mendorong kemitraan dan pelibatan keluarga dalam memajukan pendidikan anak mereka.

Hasil penelitian ini sejalan dengan temuan dari Morrison (1988, dalam Patmonodewo, 2003: 125) yang mengemukakan tiga kemungkinan kemitraan orang tua, yaitu : (1) orientasi pada tugas, yaitu harapan kemitraan orang tua dalam membantu program sekolah yang berkaitan sebagai staff pengajar staf administrasi, sebagai tutor, melakukan monitoring dan membantu mengumpulkan dana, membantu mengawasi anak apabila anakanak melakukan kunjungan luar, serta membantu anak dalam tugastugas sekolah. (2) orientasi pada proses, kemitraan orang tua dalam kegiatan yang berhubungan dengan proses pendidikan, antara lain perencanaan kurikulum, memilih buku yang diperlukan sekolah, seleksi guru, dan membantu menentukan standar tingkah laku yang diharapkan. (3) orientasi pada perkembangan, yaitu untuk mengembangkan keterampilan yang berguna bagi mereka sendiri, anak-anaknya, sekolah, guru, keluarga, dan pada waktu yang bersamaan meningkatkan keterlibatan orang tua.

Pembentukan Komite Sekolah bertujuan untuk: 1) mewadahi dan menyalurkan aspirasi dan prakarsa masyarakat dalam melahirkan program kebijakan sekolah; 2) meningkatkan tanggung jawab dan peran serta aktif seluruh lapisan masyarakat dalam penyelenggaraan pendidikan; 3) menciptakan suasana dan kondisi transparan, akuntabel dan demokratis dalam penyelenggaraan pendidikan. Sedangkan peran yang dijalankan Komite 
Sekolah adalah: 1) sebagai pemberi pertimbangan dalam penentuan dan pelaksanaan kebijakan pendidikan di sekolah; 2) sebagai pendukung finansial, pemikiran, tenagadalam penyelenggaraan pendidikan di sekolah; 3) sebagai pengontrol dalam rangka transparansi dan akuntabilitas penyelenggaraan dan keluaran pendidikan di sekolah; 4) sebagai mediator antara pemerintah dan masyarakat sekolah (Depdiknas, 2003: 12). Sementara itu, fungsi Komite Sekolah adalah: 1) memberikan masukan, pertimbangan, dan rekomendasi kepada sekolah mengenai kebijakan dan program pendidikan, kriteria tenaga kependidikan, fasilitas pendidikan; 2) mendorong orang tua dan masyarakat berpartisipasi dalam pendidikan dan menggalang dana masyarakat dalam rangka pembiayaan penyelenggaraan pendidikan di sekolah. Perkembangan merupakan rangkaian proses perubahan ke arah yang lebih maju dan lebih dewasa.

Mengembangkan kreativitas sejak diniitusangatpentingbagiperkembangan anak karena ada beberapa perilaku yang mencerminkan perilaku kreativitas alamiah anak pra sekolah menjadi nyata seperti menjajaki lingkungannya, dan rasa ingin tahu mereka sangat besar. Konsep yang sesuai dengan partisipasi orang tua dalam program PAUD adalah konsep kemitraan (partnership concept).

Konsep ini diperlukan oleh lembaga untuk meningkatkan partisipasi orang tua. Sehingga minat orang tua terlibat dalam pendidikan anak usia dini di rumah dan sekolah merupakan prediktor yang positif terhadap proses dan prestasi belajar anak, maka dapat ditengarai orang tua yang jarang terlibat akan terjadi kendala dalam proses dan prestasi belajar anak atau model kemitraan yang terjalin adalah komunikasi dua arah antara orang tua dan guru. Saling menghormati dan dukungan antara pendidik dan orang tua Pengambilan keputusan bersama antara sekolah dan keluarga fokus pada peningkatan belajar anak di sekolah dan di rumah. Guna membangun kemitraan dan memberdayakan orang tua, sekolah dapat memberikan tutorial, tugas monitoring dan workshop yang sesuai bagi orang tua untuk memberikan materi kepada mereka tentang bagaimana membantu mereka memahami tentang anak-anak mereka yang prestasinya rendah. Program ini menunjukkan bahwa sekolah peduli terhadap orang tua dan keberhasilan anak-anak mereka. ikan anak mereka.

Bentuk kemitraan antara sekolah dengan keluarga dapat dilakukan melalui: 1) kegiatan pertemuan orang tua, 2) keterlibatan orang tua orang tua di dalam kelas anak 3) keterlibatan orang tua dalam acara bersama, 4) Hari konsultasi anak.

Dampak adanya kolaborasi antara sekolah dengan keluarga adalah: 1) siswa dapat berperilaku dan menunjukkan prestasi yang lebih baik di sekolah, 2) memberikan kontribusi yang positif dalam prestasi akademis, frekuensi kehadiran anak, iklim sekolah, persepsi orang tua dan anak tentang belajar di kelas, sikap dan perilaku positif anak, kesiapan anak untuk mengerjakan PR, peningkatan waktu yang dihabiskan anak bersama orang tuanya, aspirasi pendidikan, kepuasan orang tua terhadap guru, dan kesadaran anak terhadap well being, 3) memberi efek positif pada berbagai aspek pendidikan termasuk meningkatkan perilaku anak dan adaptasi 
social, mengurangi masalah kedisiplinan di sekolah, meningkatkan kesuksesan di sekolah, dan peningkatan kehadiran di sekolah, 4) intensitas dukungan keluarga berpengaruh meningkatkan pencapaian perkembangan anak usia dini (usia 0-6 tahun), 5) kemitraan dan peran aktif orang tua di sekolah berpengaruh meningkatkan kemajuan dan kesuksesan anak-anak mereka.

Irene (2011: 65) menyatakan bahwa interaksi yang terjalin antara orang tua dan sekolah meliputi dua kategori yaitu parental involvement dan participation. Begitu pula yang dikemukakan Davis bahwa parental involvement adalah partisipasi orang tua pada jenis aktivitas yang ditujukan untuk mendukung program- program sekolah, sedangkan participation adalahorang tuaberpengaruh atau berupaya mempengaruhi dalam pengambilan keputusan pada hal-hal yang sangat penting di sekolah, seperti penentuan program sekolah dan lainlain (Irene, 2011: 65). Dengan demikian partisipasi orang tua sangat penting demi kemajuan suatu lembaga pendidikan.

Hal ini selaras dengan Morrison (2012: 382-383) yang menjelaskan bahwa cara untuk melakukan pengasuhan dan pendidikan bagi anak, program pelatihan bagi orang tua untuk menjadi pendamping kelas anak, dan pendukung aktivitas belajar merupakan beberapa bentuk kegiatan parenting. Dengan adanya parenting, pihak sekolah mengharapkan agar orangtua menyadari kemampuan anaknya, tidak banyak menuntut terutama pada anak yag mau SD. Orang tua diharapkan paham dengan perkembangan anak sendiri karena masing-masing anak berbeda. Hal ini sesuai dengan teori menurut
Coleman (2013: 74) yang menyatakan bahwa salah satu manfaat bagi orangtua dengan adanya kerjasama dengan pihak sekolah adalah memberikan informasi pada orangtua tentang perkembangan anak selama di kelas yang berguna bagi orang tua untuk memberikan tindak lanjut ketika di rumah.

Ada beberapa strategi yang dapat ditempuh dalam mengembangkan kemitraan antara sekolah dan masyarakat, di antaranya:

1. Mendorong pemanfaatan sumbersumber daya dalam masyarakat dan voluntir untuk memperkaya kurikulum sekolah.

2. Mengembangkan kemitraan dalam pendidikan antara sekolah, masyarakat dan pusat-pusat penyedia layanan swasta.

3. Memanfaatkan fasilitas-fasilitas yang ada di masyarakat untuk kegiatan pendidikan seperti pusat layanan masyarakat untuk pertemuan terkait dengan kegiatan pendidikan, sosial, budaya, dan kebutuhan rekreasional untuk seluruh masyarakat dari berbagai lapisan dan usia.

4. Menciptakan lingkungan masyarakat yang menopang terjadinya pembelajaran sepanjang hayat.

5. Membangun keterlibatan masyarakat dalam proses perencanaan dan pengambilan keputusan di bidang pendidikan.

6. Menyediakan forum saran, suatu komunitas berbasis saling mensupport untuk mewujudkan aksi bersama antara semua komponen pendidikan dan agen- 
agen sosial menuju terciptanya kehidupan masyarakat yang lebih baik dan kebutuhan-kebutuhan khusus.

7. Mengembangkan sistem yang memfasilitasi keluarga, sekolah dan masyarakat dapat berkomunikasi (Decker and Decker, 2003: 6).

Dalam mengembangkan kemitraan sekolah, sekolah perlu mengidentifikasi potensi resources yang ada di sekitarnya kemudian mengorganisir resources tersebut untuk mensupport eksistensi sekolah. Segala potensi yang ada di sekitar sekolah mampu menjadi penopang keunggulan sekolah, manakal diberdayakan secara tepat dan optimal.

Pentingnya kemitraan sekolah dan keluarga adalah: 1) Keluarga adalah pendidik yang pertama dan utama, tetapi dalam praktiknya masih banyak keluarga yang menyerahkan sepenuhnya tanggung jawab pendidikan anak pada sekolah, 2) Peran sekolah adalah membantu keluarga agar pelaksanaan pendidikan lebih sistimatis, efektif, dan hasilnya tersertifikasi, 3) Tidak semua kebutuhan pendidikan anak dapat dipenuhioleh satuan pendidikan maupun keluarga, 4) Kerjasama keluarga dengan satuan pendidikan mutlak diperlukan, 5)Satuan pendidikan wajib mendorong kemitraan dan pelibatan keluarga dalam memajukan pendidikan anak mereka. Berdasarkan berbagai hasil penelitian menunjukkan bahwa dengan adanya kolaborasi antara keluarga dan sekolah berpengaruh meningkatkan kemajuan dan kesusksesan anak-anaknya.

Selama ini, banyak sekolah yang merasa tidak percaya diri dengan potensi di sekitar sekolah yang dianggap "pinggiran", padahal justru keadaan demikian dapat menjadi daya tarik bagi sekolah yang bersangkutan manakala mampu mensinergikan dengan trend modernitas global. Dengan kata lain, kita bisa mengglobalkan kelokalan kita.

\section{IV.SIMPULAN}

Idealnya setiap program PAUD itu membuat perencanaan partisipasi orang tua agar mempunyai kesiapan yang aktif. Kesiapan aktif pada program PAUD harus bisa mengarahkan bermacammacam bentuk partisipasi orang tua sesuai dengan kelompok sosial orang tua, pendidikan, mata pencaharian walaupun dalam bentuk atau kesempatan yang berbeda, sehingga perencanaan partisipasi orang tua lebih optimal. Hubungan silaturahmi dan kerjasama antara lembaga PAUD dengan orang tua dan masyarakat peserta didik bisa dicapai secara maksimal dan meningkatkan peranan orang tua anak usia dini dan masyarakat dalam pelaksanaan programprogram lembaga PAUD.

\section{DAFTAR PUSTAKA}

Beaty, J. J. 1984. Skills for Preschool Teachers. Columbus: Charles E. Merrill Publishing Company.

Berger, E.H. 1991. Parent as Partners in Education. New York: Mac Millian Publishing Company.

Bern, R.M. 2004. Child, Family, School, and Community. Colonia Polanco: Thomson Learning.

Brewer, J. 2007. Introduction to Early Childhood Education. Preschool Through Primary Ade Grades. New York: Pearson.

Buchori, M. 2001. Pendidikan Antisipatoris. Yogyakarta: Kanisius 
Coleman,J.S.2009. Dasar-Dasar Teori Sosial. (Terjemahan Imam Muttaqien, Derta Sri Widowatie, SiwiPurwandari). Bandung: Nusa Media.

Decker, L.E \& Decker, V.A. 2003. Home, School, and Community Partnership. Oxford: Scarecrow Press, Inc.

Depdiknas. 2002. Manajemen Peningkatan Mutu Berbasis Sekolah: Konsep dan Pelaksanaan. Jakarta: Depdiknas Direktorat SLP.

Depdiknas. 2003. Indikator Kinerja Dewan Pendidikan dan Komite Sekolah. Jakarta: Proyek Publikasi dan Sosialisasi Pendidikan.

Depdiknas. 2003. Undang-undang RI Nomor 20, Tahun 2003, tentang Sistem Pendidikan Nasional.

Dwiningrum, Siti Irene A. 2011. Desentralisasidan Partisipasi Masyarakat Dalam Pendidikan: Suatu Kajian Teoretis dan Empirik. Yogyakarta: Pustaka Pelajar.

Epstein, J.L. 2009. School, Family and Community Partnership. California: Crown Press.

Hornby, G. 2011. Parental Involvement in Childhood Education: Building Effective School-Family Partnership. New York: Springer Sciencet Business Media.

Hornby, G. dan Rayleen, L. 2011. Barriers to Parental Involvment in Education: An Explanatory Model. College of education - Univercity of Canterbury, New Zeland.
Jeynes, W.H. 2007. The relation between parental involvement and urban secondary school student academic achievement: A meta-analysis. Urban Education, 42(1), 82-110.

Milles, M.B. \& Huberman, A.M. 1994. Qualitative Data Analysis. Beverly Hills: Sage Publication.

Morrison, G. S. 1988. Education and Development of Infant, Toddlers, and Preschoolers. London: Scott Foresman and company.

Morrison, G. S. 1988. Early Childhood Education Today. Columbus: Merill Publishing company.

Mulyasa, E. 2007. Menjadi Kepala Sekolah Efektif. Bandung: Remaja Rosdakarya.

Olsen, G. \& Fuller, M. L. 2003. HomeSchool Relations: Working Successfully With Parent and Families. (2nd ed). Boston: Allyn and Bacon.

Sugiyono. 2011. Metode penelitian Manajemen. Bandung: Alfabeta.

Sujiono, Y.N. 2011. Konsep Dasar Pendidikan Anak Usia Dini, Jakarta: PT Indeks.

Powell, D.R. 2000. Relation Between Families and Early Childhood Programs. Http://Ecap.crc.illionis.edu/pubs/ connecting/powell.pdf 141-154

Undang-Undang Nomor 20 Tahun 2003 Tentang Sistem Pendidikan Nasional

Wortham, S. C. 2013. Early Childhood Curriculum: Developmental Bases for Learning and Teaching. New Jersey: Pearson Education Inc. 